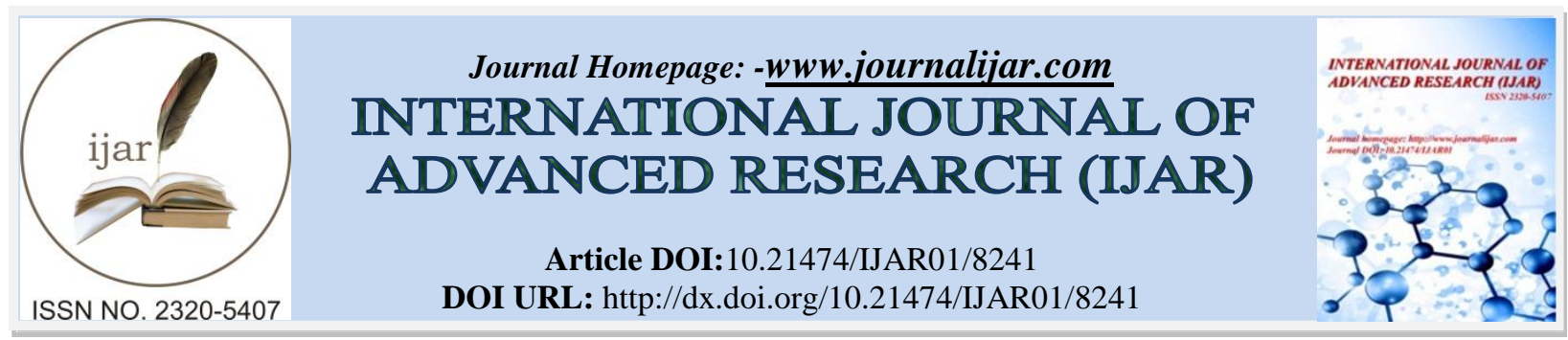

RESEARCH ARTICLE

\title{
HIGHER EDUCATION MANAGEMENT INFORMATION SYSTEM BASED WEBSITE AND MOBILE APPLICATIONS.
}

\section{Rudi Hartono ${ }^{1}$, Mukhneri ${ }^{2}$ and Wahyudi ${ }^{3}$.}

1. Universitas Djuanda, Fakultas Keguruan dan Ilmu Pendidikan.

2. Universitas Negeri Jakarta, Fakultas Keguruan dan Ilmu Pendidikan.

3. Universitas Bina Sarana Informatika, Fakultas Teknik Informatika.

\section{Manuscript Info}

\section{Manuscript History}

Received: 18 October 2018

Final Accepted: 20 November 2018

Published: December 2018

Key words:-

mobile application, management information system, college, 4D (define, design, develop, disseminate.

\begin{abstract}
Electronic devices in the form of smartphones and tablets can now be used as information sources in an effort to build a management information system in universities. These electronic devices can shorten the distance between people in the college environment and can provide easy access to anytime and anywhere. Management information systems that are widely used today are generally still based on computer devices that have limited mobility and flexibility. To facilitate access to management information systems, the use of applications on mobile devices is now starting to become a new trend. This article will share experiences about developing a mobile application-based management information system. Development is carried out by referring to the 4D model (define, design, develop, disseminate). The research was conducted in the Djuanda University Bogor. This article will specifically discuss 1) the stage of developing a mobile application for a college management information system; 2) use the application within the scope of the university; and 3) supporting factors and inhibiting the use of applications.
\end{abstract}

Copy Right, IJAR, 2017,. All rights reserved.

\section{Introduction:-}

Information and communication technology has developed very rapidly, so that the interaction and delivery of information will take place quickly. Broadly speaking, information technology can be grouped into two parts: software (software) and hardware (hardware). Hardware is related to physical equipment, such as memory, printers, and keyboards. This software is related to instructions for managing hardware to work according to the purpose of the instructions.

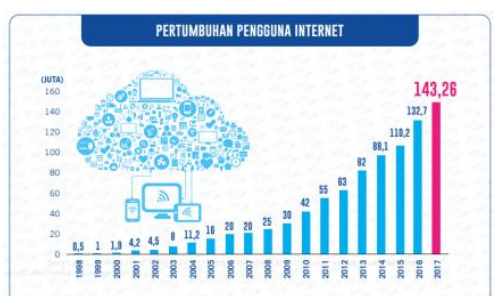

Sumber:-Survei Internet APJII 2017 - Asosiasi Penyelenggara Jasa Internet 
Smartphones play a very important role in internet usage by $52 \%$, outperforming the use of computers or laptops.

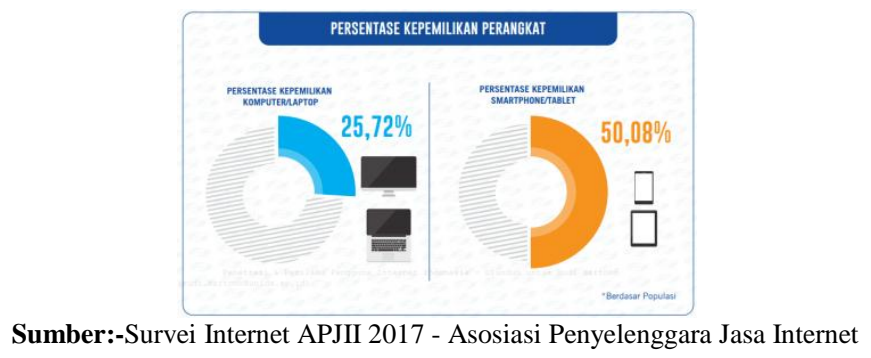

The percentage of ownership of devices using computers or laptops is $25.72 \%$ and the ownership percentage of smartphone or tablet devices is $50.08 \%$ in Indonesia at this time. Therefore, access to information technology is currently more likely to use a smartphone or tablet because it is easy to carry everywhere on the move. Survey data in a smaller scope, namely in the Djuanda University area of Bogor, shows the same thing. As shown in Figure 2, $83.1 \%$ of internet users at Djuanda University in Bogor stated that they often access the internet through smartphone devices. The remaining $16.9 \%$ access the internet through laptops, PCs and other devices.

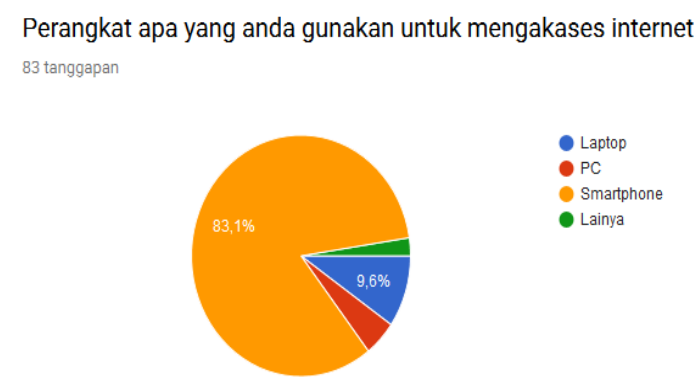

Sumber:-Google survey Universitas Djuanda.

This high internet access via smartphone provides an opportunity to use it for easy access to information relating to the interests of a university

Djuanda University Bogor as one of the leading universities in the West Java region continues to grow in terms of the use of technological devices. These developments need to be accompanied or harmonized with the integration of access to information so that work units can easily obtain and access information. Integrated access to information is expected to accelerate decision making appropriately. This study seeks to develop a Management Information System (SIM) at Djuanda University Bogor that provides accurate and integrated information and can be easily accessed through websites and smartphone devices.

This research was conducted with the aim of developing a Management Information System (SIM) in higher education, in this case Djuanda University Bogor, which is based on mobile applications on smartphone devices. This study also aims to determine the use of SIM-based mobile applications and to find out the supporting factors and inhibitors in their use

\section{Theoritical review:-}

A. Management information systems (SIMs) are sometimes called management alerting systems, because this system gives a warning to users (generally management) of problems and opportunities. Another term for SIM is the management reporting system. The system comes from Latin (systema) and Greek (sustema) is a unit consisting of components or elements that are linked together to facilitate the flow of information, matter or energy. This term is often used to describe an entity that interacts. The system can also be defined as a collection or set of elements or variables that are mutually organized, interacting, and interdependent with each other. SIM is an information system that functions to manage information for organizational management. Information in the organization plays the role of blood in the human body. Healthy information flow is needed by an organization to stay alive. Within the organization, SIM functions both for management control and as a decision support system. The concept of SIM has 
been born since before the computer was used, but all kinds of information in the organization must be processed carefully, quickly, and reliably. However, without computers, concepts it only becomes a theory. Now with the advancement of technology and the widespread use of computers as primary needs, the SIM concept can be applied in an organization (Nugroho, 2008).

Educational institutions in Indonesia are organizations that have multiple orientations, namely socially oriented organizations and business orientations. The social orientation of education aims to improve the intelligence of the nation, while the business orientation of education in maintaining its existence and operations must have sufficient funds. Thus, the educational institution will produce quality outcomes. Many educational institutions have emerged that dare to set high tuition fees, because the learning facilities and infrastructure provided are also much better and promise to students and students to take part in internships in well-known companies. Thus, it is possible that those who excel will be directly recruited by the company. The product of education management information system that is needed by Indonesia ideally is how educational decision makers can easily find information as material in the education decision-making process. For example, how many educational human resources are needed, the type of school, the level of school, the implementation of the curriculum, the development of local, regional, national, and even international education institutions in order to improve the performance of the past, present, and future education world. In the face of globalization, the world of Indonesian education must immediately improve itself in improving information systems to support the competitiveness of human resources produced by these educational institutions. The management information system that will be implemented must be balanced between available technological infrastructure and human resource capabilities, so that there is no very long imbalance, and information systems cannot be realized significantly in supporting the quantity and quality of education fundamentally.

In addition to this, information systems are increasingly needed by educational institutions, especially in increasing the smooth flow of information in educational institutions, quality control, and creating alliances or cooperation with other parties that can increase the value of the education institution. Higher education is a level of education after secondary education that includes diploma education programs, bachelor, master, specialist, and doctoral degrees held by higher education. Higher education is held with an open system. Higher Education is an educational unit that organizes higher education and can take the form of academies, polytechnics, high schools, institutes, or universities.

Higher education is obliged to organize education, research, and community service. Colleges can hold academic, professional and / or vocational programs. Academic, professional or vocational degrees are only used by graduates from universities who are declared entitled to provide academic, professional, or vocational degrees.

\section{Smartphone Platform:-}

Android is a platform for operating systems on mobile phone devices that are open source and based on the Linux kernel. This platform allows developers to create programs in the Java programming language. Manage devices through Google's Java Libraries. This platform supports a number of connecting technologies including GSM / EDGE, CDMA, EV-DO, UMTS, Bluetooth, and Wi-Fi Apple App Store is an application distribution platform for iOS developed and managed by Apple Inc. This service allows users to browse and download applications developed with the Apple iOS SDK. The application can be downloaded directly to an iOS device or personal computer (Macintosh or PC) through iTunes. Apps in the App Store are generally targeted at iOS devices such as the iPhone and iPad and can take advantage of special features on devices such as motion sensors for game control and cameras for online video calls. The application can be downloaded for free or at a set price. Besides that, you can also use monetization methods in applications such as advertising or purchasing items. Apple takes 30 percent of the profits obtained through the application and the remaining 70 percent is returned to the application manufacturer.

\section{Djuanda University Bogor:-}

Djuanda University Bogor is one of the leading private universities in the West Java region under the auspices of the Foundation Indonesian Amaliyah Islamic Study and Development Center (YPSPIAI). Djuanda University is on the Ciawi Toll Road Number 1 Ciawi, Bogor Regency, West Java There are 7 faculties in Djuanda University, namely Faculty of Law (FH), Faculty of Economics (FE), Faculty Islamic Economics (FEI), Faculty of Agriculture, Faculty of Social and Political Sciences (FISIP), Teacher Training and Education Faculty (FKIP), Halal Food Faculty, and Postgraduate School. At present the University Djuanda has almost 6000 active students. 


\section{Research Methods:-}

This research is research and development (Reseacrh and Development / R \& D). The R \& D method is a research method used to produce certain products and test the effectiveness of these products. Sukmadinata (2009) defines R \& D research is a process or steps to develop a new product or perfect existing products that can be accounted for. The product developed in this study is a mobile application SIM for college, in this case Djuanda University Bogor. Product development refers to the 4D development model or Define Design-Develop-Disseminate (Thiagarajan: 1974). At the define stage, an analysis of needs is carried out so that it can be explored problems that will be sought to solve through the products developed. The design is carried out at the design stage. The design carried out included the formulation of a mobile application flowchart, storyboard formulation, and product drafting. At the develop stage, the draft product that has been designed is then realized as a whole product that is ready for use. At this stage the product is then validated and tested. Validated and tested products can then be used and disseminated at the disseminate stage Product validation and testing is carried out to lecturers, students, and staffing staff in several faculties within the Djuanda University Bogor. Validation and testing are conducted to measure aspects of product design, appearance, readability, and effectiveness. Product revisions are based on input and results of trials. Data was collected using assessment questionnaires, observation sheets, and interview sheets. The collected data is then analyzed descriptively qualitatively.

\section{Results and Discussion:-}

\section{A. Product Development:-}

The product in the form of a Djuanda Bogor University SIM based on mobile application was developed because of the view the need for information integration and rapid information access needs in management in the environment Djuanda University Bogor.

Current academic and financial services have been carried out with the help of computers and adequate internet networks. The Academic Information System (SIMAK) service of Djuanda University can now be developed to improve services to the academic community by providing accurate and fast data. SIMAK can be accessed through the www.simak.unida.ac.id website since 2017.

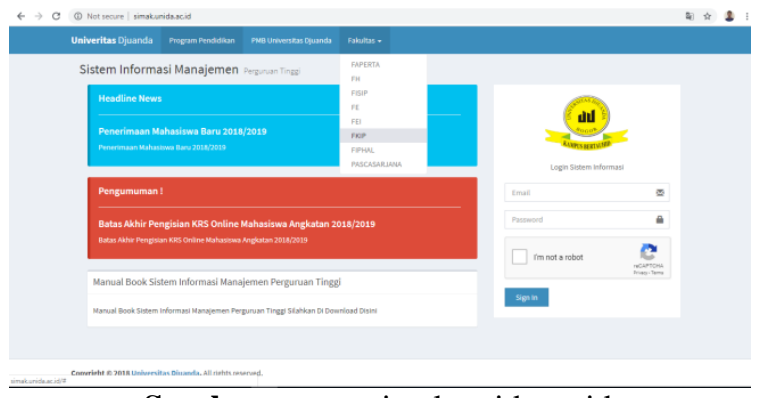

Sumber:-www.simak.unida.ac.id

These SIM subsystems include:-

1. New student admission subsystem

2. Academic Subsystem

3. Financial subsystem

In addition there are also several supporting subsystems, including:-

1. Student subsystem

2. Lecturer subsystem

3. Personnel subsystem

4. Faculty subsystem

SIMAK's services have integrated academic information that can be accessed by students, lecturers, staff, faculty, and financial units by first logging in using a registered account 


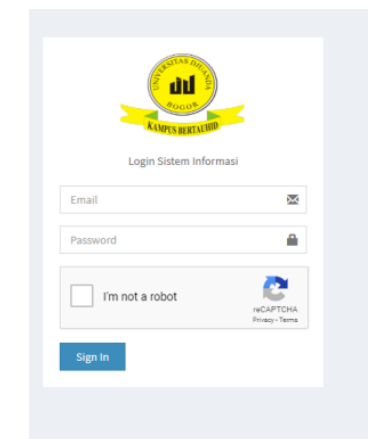

Sumber:-login www.simak.unida.ac.id

Student login services can provide access to profiles, Study Plan Cards (KRS), grades, courses, lecture materials, payments, exam cards, and final assignments. The lecturer login service gives access to daily attendance, profiles, research and service, teaching schedules, assigning grades, student data, to lecturer performance loads Financial login services provide access to student financing, financial administration, utilities, and financial reports. The faculty login page provides access to curriculum, study programs, lecturer data, student data, lecture schedules, and grades.

The login page for new student admissions (PMB) provides access to registration, entrance examination, graduation, and re-registration.

This research then developed an available SIM.

on the website it becomes a mobile application SIM that can be accessed via a smartphone device. The logic developed in the application is the same as the logic used on the website. Services that can be accessed on the SIM version of the smartphone are easier to access. The mobile application currently available is still limited to the Android platform

Applications that have been developed are then validated and tested on lecturers, students, and staff. The results of validation and testing show that this application is feasible to use by first making several revisions. Product revisions that need to be carried out include the following.

1. Errorr Click on several buttons.

2. Buttons that are not active.

3. Interface

4. Download file size of application.

For easy access, the Android version of the SIM mobile application is further eliminated through the Google Play facility. Djuanda University SIM can be downloaded for free through the Google Play page

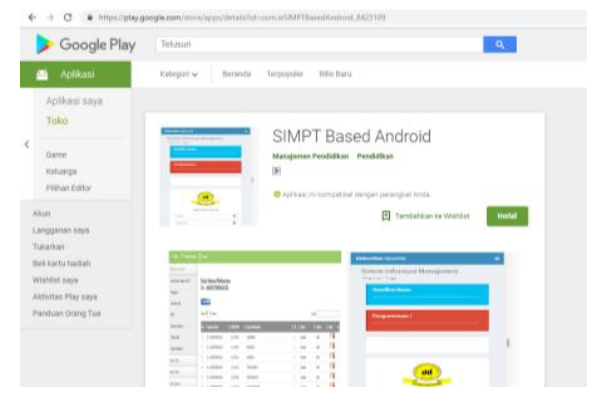

Sumber:-Management Information System in Playstore

\section{Use of Products:-}

The Djuanda University SIM product that has been successfully developed can then be used to help facilitate access to accurate and fast information in the interests of various academic and other activities at the university. SIM can be used by all students, lecturers, and staffing staff. 
Some steps that need to be implemented before the use of a SIM in a massive manner include the following:-

1. Product testing in limited circles.

2. Making use guidelines.

3. Dissemination of SIM usage.

4. Training on SIM usage at the level of lecturers, staffing staff, and students.

5. Trial use of products on a wide scale.

The process of migrating from offline management to a website-based SIM and smartphone needs to go through a relatively short-term process. SIM operators in each faculty need to be provided and trained to truly master the SIM usage operation. Furthermore, the operator can facilitate if there are obstacles in the use of SIM on daily academic activities, both within the student and lecturer environment.

\section{Supporting Factors and Inhibiting Product Use:-}

The application and use of website and smartphone-based SIMs in the university environment found obstacles and supporters in their implementation. Some of the supporting factors found include:-

1. Availability of infrastructure in higher education that facilitates the application of website-based and smartphone SIMs.

2. Stakeholder support in developing website and smartphone SIMs.

Meanwhile, the obstacles encountered in the field include, among other things, limited human resources experts.

SIM Djuanda University continues to be applied as a whole so that it reaches all the academics of Djuanda University and can facilitate the presentation of accurate and fast information so as to facilitate the right decision making.

\section{Conclusions and Suggestions:-}

Djuanda University Management Information System (SIM) has been successful developed and accessible in the form of a mobile application on the Android platform. The use of a driver's license in Djuanda University is done in stages through testing, socialization, and training on SIM usage. The use of SIM can run well with the availability of infrastructure and stakeholder support as well as adequate human resources experts.

This research needs to be continued to develop SIM mobile applications on other smartphone platforms such as iOS. Product use surveys also need to be carried out on a broader scale to find out the user's response to products that have been developed

\section{Suggestions:-}

1. Berisha, A. 2014. Management Information System and Decision-Making. Academic Journal of Interdisciplinary

2. Studies Volume 3 No.2 Juni 2014 pp 19-23.

3. Haag, S., Cumming, M., Dawkins, J. 2000. Management Information System for the Information Age, 2nd

4. Edition.

5. Irwin/McGraw-Hill.

6. Nugroho, E. 2008. Sistem Informasi Manajemen.

7. Konsep, Aplikasi, dan Perkembangannya. Penerbit Andi, Yogyakarta.

8. Hanif, A. 2007. Analisis dan perancangan sistem informasi untuk keunggulan bersaing perusahaan dan organisasi

9. modern. Andi Offset, Yogyakarta.

10. Kadir, A. 2004. Pengenalan Sistem Informasi Edisi Revisi.Andi Offset, Yogyakarta.

11. Purwanto, R. 2010. Perancangan Sistem Informasi Manajemen Aset TI di PT Nikomas Gemilang Banten. Sainten

12. volume 6 nomor 2 tahun 2010 halaman 26-36.

13. Robbins, P. Stephen \& Mary, C. 2010. Manajemen Edisi Ke $\quad 10, \quad$ Jilid $\quad 1, \quad$ terjemahan.

14. Erlangga, Jakarta.

15. Setiawan, T.D. 2009. Pengembangan Sistem Informasi Manajemen Laboratorium Teknik Mekanik Otomotif pada 
16. SMK Berbasis Database Microsoft Access. Teknologi dan Kejuruan, volume 32 Nomor 1 Februari 2009: 95106

17. Sukmadinata, N.S. 2009. Metode penelitian pendidikan. Remaja Rosdakarya, Bandung.

18. Thiagarajan. 1974. Instructional Development for Training Teachers of Exceptional Children.

19. Indiana University,

20. Blomington Indiana.

21. Thomas, P. 2010. Peran Sistem Informasi

22. Manajemen "Management Information System" dalam Meningkatkan Kualitas Pendidikan Kejuruan. Seminar

23. APTEKINDO Tahun 2010 halaman 429434. 